\section{Environmental Physiology of Growth and Flowering of Orchids}

\author{
Roberto G. Lopez ${ }^{1}$ and Erik S. Runkle ${ }^{2}$ \\ Department of Horticulture, Michigan State University, East Lansing, MI 48824
}

\begin{abstract}
Flowering potted orchids has become one of the largest segments of floriculture worldwide. Large-scale production of cuts or potted plants exists in China, Germany, Japan, The Netherlands, Taiwan, Thailand, and the United States. Despite the value of orchids, the flowering physiology of most orchid genera is not well described. Therefore, scheduling flowering crops for specific market dates (such as Easter or Mother's Day) is not possible for most genera. This paper summarizes world orchid production and reviews how environmental factors regulate growth and flowering of several commercially important orchid genera: Cattleya, Cymbidium, Dendrobium, Miltoniopsis, Phalaenopsis, and Zygopetalum. These genera primarily flower in response to relatively low temperatures, and, for some species and hybrids, flowering is promoted when the plants are also exposed to short photoperiods. Effects of light and temperature on growth and development are summarized for these genera, and implications for controlled production are discussed.
\end{abstract}

Orchids are marketed globally as cut flowers for corsages, floral arrangements, and bouquets; as potted flowering plants; and as bedding or aerial plants in tropical regions. In 1995, worldwide demand for orchids grown for cut flower and potted plant production was 1.3 billion units of plant stock (Hew and Yong, 1997). The world consumption of orchids (potted plants) was valued at more than $\$ 500$ million in 2000 (Wang, 2004). Countries with large-scale potted orchid production include China, Germany, Japan, The Netherlands, Taiwan, Thailand, and the United States (Griesbach, 2000). The Dominican Republic, Costa Rica, and India have recently begun to produce orchids for export (Laws, 2004).

Commercial production of potted orchids has increased dramatically throughout the world in the past quarter century. In Japan, the reported value of potted orchids increased $1125 \%$ from 1965 to 1991 (Ichihashi, 1997). The most common genera sold in Japan from 1993 to 2002 were Phalaenopsis (30\%), nobile-type Dendrobium (20\%), Oncidium $(20 \%)$, Cymbidium $(15 \%)$, and Cattleya $(10 \%)$ (Hew and Yong, 1997; Laws 2004). In The Netherlands, Phalaenopsis has become the most valuable potted crop sold; from 1983 to 2003, the number of potted orchids sold through Dutch flower auctions increased from 50,000 to 18 million pots (Barendse, 2002; Laws, 2004; Wang, 2004).

TheU.S. Department of Agriculture(USDA) National Agricultural Statistical Service considered orchids to be a minor crop and did

Received for publication 5 July 2005. Accepted for publication 2 Sept. 2005. We gratefully acknowledge funding by Michigan's plant agriculture initiative at Michigan State University (Project GREEEN), the Michigan Agricultural Experiment Station, The Fred C. Gloeckner Foundation, and greenhouse growers providing support for Michigan State University floriculture research. We also thank Yin-Tung Wang and Donald Garling for their contributions to this manuscript.

${ }^{1}$ Graduate student.

${ }^{2}$ Assistant professor and extension specialist. To whom reprint requests should be addressed; e-mail runkleer@msu.edu. not collect production information until 1997 (USDA, 1998). From 1996 to 2004, U.S. potted orchid production value increased by $170 \%$, and in 2004, its wholesale value was estimated at \$128 million(USDA, 1998, 2005). Orchids are presently the second most valuable flowering potted crop in the United States, of which $70 \%$ to $90 \%$ are Phalaenopsis (Griesbach, 2002; Nash, 2003). In 2004, growers in California, Florida, and Hawaii produced $>85 \%$ of all the orchids sold in the United States, with wholesale values reported at $\$ 50, \$ 47$, and $\$ 17$ million, respectively (USDA, 2005).

Most orchids are grown for the aesthetic beauty of their flowers. However, published research on the flowering physiology of most orchid genera in controlled environments is limited. Therefore, with the exception of a few genera (e.g., Phalaenopsis and some Cattleya), the ability to coordinate the flowering process with specific sales dates is not possible. Here, we summarize the published, scientific literature on how environmental parameters (primarily, temperature and light) influence the development of some of the most commonly produced orchid genera. In addition, research results from studies performed at Michigan State University are presented.

This summary includes research on selected orchid species and hybrids performed during the past 50 years. Hybridization of orchids is commonplace, and thousands of named cultivars exist. Therefore, because of the genetic diversity of genera and intergeneric hybrids, some hybrids may respond differently than results presented in this summary.

\section{The Juvenile Phase}

Similar to that of many other flowering plants, a juvenile phase exists in orchids in which they must reach a certain stage of growth (or maturity) before attaining the capacity to flower. Thus, sexual reproduction is delayed until plants reach a size sufficient to maintain the energetic demands of flowering and seed production. This period of juvenility varies among species and hybrids. Four to seven years are required for many orchids to flower from seed (Goh and Arditti, 1985), but many commercially important hybrids flower within 36 months of germination (Hew and Yong, 1997). Once plants have attained the capacity to flower, environmental or cultural factors can be provided to induce flowering. If conditions are unfavorable, plants may not initiate flowers, or a potential inflorescence may not develop flowers to anthesis. However, once buds have developed to a certain size (e.g., about $3 \mathrm{~mm}$ in Aranda hybrids), they usually continue to develop to anthesis unless exposed to extreme temperature or prolonged darkness (Goh and Arditti, 1985).

\section{Cattleya}

Cattleya is a genus composed of 48 species originating throughout tropical regions of Central and South America (Pridgeon, 2000). The epiphytic plants are found growing atop trees of moist and wet forests from sea level to $1500 \mathrm{~m}$ in elevation. Similar to many other tropical orchid genera, growth is more rapid at high temperature (e.g., $>25^{\circ} \mathrm{C}$ ). For example, vegetative growth of Laeliocattleya Culminant 'La Tuilerie' was greater when plants were grown in a growth chamber at a day/night temperature of $32 / 29^{\circ} \mathrm{C}$ compared with that in a $24 / 20^{\circ} \mathrm{C}$ greenhouse (Krizek and Lawson, 1974). After 17 weeks, leaf elongation was 4.5 times greater at the warmer temperatures, and after 24 weeks, plants developed two or three lateral shoots compared with just one at the lower temperatures. According to Rotor (1952), 9-h short days stimulated vegetative growth because plants produced two successive growths under this daylength, but not under long days or natural photoperiods. The maximum recommended light intensity for Cattleya orchids is between 300 and $600 \mu \mathrm{mol} \cdot \mathrm{m}^{-2} \cdot \mathrm{s}^{-1}$ (Dole and Wilkins, 1999).

Cattleya species and hybrids flower at different times throughout the year. Some Cattleya initiate flower buds in response to low temperature and short photoperiod during the spring, but buds do not enlarge and reach anthesis until autumn or winter (Table 1). Thus, environmental conditions for flower bud initiation and flowering can be different (Rotor, 1952). In C. warscewiczii Rchb.f, $C$. gaskelliana Rchb.f, and C. mossiae Hkr, flower induction occurred under continuous 9-h days at $13{ }^{\circ} \mathrm{C}$, whereas few plants flowered under 16-h days at $13{ }^{\circ} \mathrm{C}$ (Rotor, 1952, 1959). Cattleya warscewiczii apparently requires short days and low temperature as the pseudobulb develops for the most rapid flowering (Rotor, 1952). Flowering was reduced and delayed (by 2 to 3 months) when plants were grown under short days at $18^{\circ} \mathrm{C}$ compared with plants under short days at $13{ }^{\circ} \mathrm{C}$.

In $C$. labiata Lindley and $C$. schilleriana Rchb.f, 16-h long days at $18{ }^{\circ} \mathrm{C}$ prevented flowering (Rotor, 1952, 1959). Cattleya labiata and C. schilleriana flowered under short days, regardless of the growing temperature, and flowered under long days if the temperature was maintained below $16^{\circ} \mathrm{C}$. In a separate study, Cattleya bowringiana Veitch grown under an 8-h photoperiod flowered in $273 \mathrm{~d}$, whereas 
plants grown under a 16-h photoperiod did not flower during the duration of the experiment (Goh and Arditti, 1985).

Goh and Arditti (1985) present a schedule for flowering C. gaskelliana for the Christmas holiday in the northeastern United States. They suggest growing plants under warm conditions $\left(\geq 16{ }^{\circ} \mathrm{C}\right)$ during the previous November, December, and January, when new pseudobulbs normally begin to develop. Plants should receive short days from February through September, and in the autumn, the night temperature should be reduced to $13{ }^{\circ} \mathrm{C}$. Flowering is expected to occur about 3 to 4 months after flower initiation.

\section{Cymbidium}

Cymbidium is a genus of approximately 44 species native from the Himalayas to tropical regions of southeast Asia to Australia (Pridgeon, 2000). The terrestrial, epiphytic, lithophytic, and semiepiphytic species require long days and day/night temperatures of 30/25 ${ }^{\circ} \mathrm{C}$ for rapid growth and pseudobulb maturity (Ichihashi, 1997; Pridgeon, 2000) (Table 1). During the warm summer in Japan, several orchid genera (including Cymbidium) are commonly transported from production areas in the lowlands to higher elevations. This strategy helps prevent high-temperature stress during vegetative growth and exposes plants to cooler temperatures and higher light for flower initiation (Ichihashi, 1997).

Due to the large geographic distribution of Cymbidium, they are often divided into three horticultural groups based on their temperature tolerance: cool, intermediate and warm. Most large-flowered Cymbidium species from the Himalayas and China are induced to flower by a pronounced cool period in which night temperature is kept at about 10 to $14{ }^{\circ} \mathrm{C}$ (Pridgeon, 2000; Rotor, 1952, Went, 1957). Went (1957) found that Cymbidium giganteum var. lowianum Rchb. f. did not flower when grown for 1 to 3 months at $26 / 14^{\circ} \mathrm{C}$ or $23 / 14$ ${ }^{\circ} \mathrm{C}$; some inflorescences developed at $26 / 7^{\circ} \mathrm{C}$ or $26 / 10^{\circ} \mathrm{C}$, and the greatest floral production occurred at $20 / 10^{\circ} \mathrm{C}$ and $20 / 14^{\circ} \mathrm{C}$. Thus, the day and night temperature likely have an effect on flower induction, not the night tempera- ture alone. Cymbidium growers in California provide relatively high light intensities (up to full sun in winter) and night temperatures of 10 to $13{ }^{\circ} \mathrm{C}$ for flower bud initiation (Goh and Arditti, 1985). In Japan, the temperature commonly used for flower induction is between 10 and $16^{\circ} \mathrm{C}$, and the cumulative temperature required for flower bud differentiation is 34,000 ${ }^{\circ} \mathrm{C}$-hours (calculated by multiplying the hours of exposure to 10 to $16^{\circ} \mathrm{C}$ by the temperature, e.g., $118 \mathrm{~d}$ at $12^{\circ} \mathrm{C}$ ) (Ichihashi, 1997).

Many temperate Cymbidium hybrids derived from the "Asiatic Cymbidium Belt" are reported to flower in response to warm days and cool nights, with a diurnal temperature fluctuation of 10 to $14^{\circ} \mathrm{C}$. Powell et al. (1988) reported that Cymbidium Astronaut 'Rajah' exposed to day/night temperatures of $26 / 12^{\circ} \mathrm{C}$ and a $14-\mathrm{h}$ photoperiod produced an average of 5.9 inflorescences per plant. At $20 / 12^{\circ} \mathrm{C}$ or $26 / 18^{\circ} \mathrm{C}$, only 0.8 and 1.7 inflorescences per plant developed, respectively. Temperature $\geq 25$ ${ }^{\circ} \mathrm{C}$ can cause flower bud blasting (abortion) in the early stages of development in many intermediate-and miniature-sized Cymbidium orchids such as Cymbidium pumilum and Cymbidium Sazanami 'Haru-no-umi' (Ichihashi, 1997; Ohno, 1991).

Cymbidium orchids originating from warm regions such as Taiwan and Southern China normally flower in the summer (Lee and Lee, 1993). Pseudobulb development and flower formation in Cymbidium ensifolium var. misericors were accelerated at warm day/night temperatures of $30 / 25$ and $25 / 20$ ${ }^{\circ} \mathrm{C}$, and were deterred at $20 / 15^{\circ} \mathrm{C}$. At $30 / 25$, $25 / 20$ and $20 / 15^{\circ} \mathrm{C}$, plants with 1 to 2 year mature psuedobulbs produced $2.3,1.6$, and 1.1 inflorescence, respectively (Lee and Lee, 1993). To our knowledge, no studies have reported photoperiod to have an effect on flower induction (Goh and Arditti, 1985; Goh et al., 1982; Went, 1957).

In vitro flowering of Cymbidium niveomarginatum Lindl. has been achieved with a combined treatment of cytokinin (6-benzylaminopurine), restricted nitrogen, enriched phosphorus, and root excision (pruning) (Kostenyuk, et al., 1999). In vivo, C. niveomarginatum requires 4 to 7 years before it can flower. However, this flower-stimulating technique has limited or no commercial application.

\section{Dendrobium}

Dendrobium (the spray orchid) is the second largest genera of the orchid family, with $>1,200$ epiphytic species that are native to tropical and subtropical Asia, Australia, and various Pacific Islands (Eigeldinger and Murphy, 1972; Baker and Baker, 1996). For most Dendrobium orchids, rapid vegetative growth occurs at temperatures between 24 and $30^{\circ} \mathrm{C}$ (Leonhardt, 2000)(Table 1). Dendrobium phalaenopsis Fitz var. statterianum Hort. ex Sander grown at 13 or $18{ }^{\circ} \mathrm{C}$ produced one pseudobulb per year; however, those at 13 ${ }^{\circ} \mathrm{C}$ were short and spindly (Rotor, 1952). The development of vegetative shoots was also delayed by 2 months at $13{ }^{\circ} \mathrm{C}$ (Rotor, 1952). Temperatures below $10^{\circ} \mathrm{C}$ may cause leaf drop or abscission in some species (American Orchid Society, 2002). Most Dendrobium species and hybrids can tolerate higher light intensities than other orchid genera reviewed in this article (Dole and Wilkins, 1999).

The recommended temperature for flower induction differs among Dendrobium hybrids and species. Dendrobium nobile Lindley plants exposed to $13{ }^{\circ} \mathrm{C}$ produced flowers regardless of the photoperiod, whereas plants held at $18{ }^{\circ} \mathrm{C}$ remained vegetative (Goh and Arditti, 1985; Rotor, 1952). Buds on immature Dendrobium nobile pseudobulbs remain dormant and do not respond to low temperature for flowering. Flower induction in $D$. Snowflake 'Red Star' was achieved by providing $25 / 10$ ${ }^{\circ} \mathrm{C}$ (day/night) for 40 to $60 \mathrm{~d}$. Lower day temperature can cause leaf yellowing, defoliation, and reduced growth rates; higher temperature can delay flower bud development (Ichihashi, 1997). In D. phalaenopsis, short days at $18^{\circ} \mathrm{C}$ hastened flower bud development and flowering by about 6 weeks compared with that of plants under long or natural daylengths at 18 ${ }^{\circ} \mathrm{C}$ (Rotor, 1952). At $13{ }^{\circ} \mathrm{C}$, this same tendency was observed, but flower bud development was slow because of the low temperature (Rotor, 1952).

Goh and Arditti (1985) postulated that photoperiod and low temperature modify

Table 1. Summary of the temperature and light environments that promote vegetative growth (inhibit flowering) or stimulate flowering for several orchid genera and their horticultural groups. Some species and hybrids within a genus may have different flower induction responses.

\begin{tabular}{|c|c|c|c|c|c|c|}
\hline \multirow[b]{3}{*}{ Genus } & \multicolumn{3}{|c|}{ Vegetative growth } & \multirow{2}{*}{\multicolumn{2}{|c|}{ Flower initiation }} & \multirow[b]{3}{*}{ References } \\
\hline & \multirow[b]{2}{*}{$\begin{array}{l}\text { Temp } \\
\left({ }^{\circ} \mathrm{C}\right)\end{array}$} & \multirow[b]{2}{*}{ Photoperiod } & \multirow{2}{*}{$\begin{array}{l}\text { Max } \\
\text { light intensity } \\
\left(\mu \mathrm{mol} \cdot \mathrm{m}^{-2} \cdot \mathrm{s}^{-1}\right)\end{array}$} & & & \\
\hline & & & & $\begin{array}{l}\text { Temp } \\
\left({ }^{\circ} \mathrm{C}\right)\end{array}$ & Photoperiod & \\
\hline Cattleya & $\begin{array}{l}27-32 \text { day } \\
24-29 \text { night }\end{array}$ & Short days & $300-600$ & $12-16$ & Short days & $\begin{array}{l}\text { Dole and Wilkins, 1999; Goh and Arditti, 1985; Krizek and Lawson, 1974; } \\
\text { Rotor, 1952, } 1959\end{array}$ \\
\hline Cymbidium $^{z}$ & $25-30$ & No response & $\begin{array}{r}360-600 \\
10- \\
10-14 \\
\text { (interme }\end{array}$ & $\begin{array}{l}20-26 \text { day/ } \\
-14 \text { night (co } \\
\text { diurnal fluct } \\
\text { ediate); } 25-3\end{array}$ & $\begin{array}{l}\text { No response } \\
\text { l); } \\
\text { uation } \\
0 \text { (warm) }\end{array}$ & $\begin{array}{l}\text { Dole and Wilkins, 1999; Goh and Arditti, 1985; Ichihashi, 1997; } \\
\text { Powell et al., 1988; Pridgeon, 2000; Went, } 1957\end{array}$ \\
\hline Dendrobium & $24-30$ & No response & $480-720$ & $10-13$ & Short days & Dole and Wilkins, 1999; Goh and Arditti, 1985; Ichihashi, 1997; \\
\hline D. phalaenopsis & & & & 18 & Short days & Leonhardt, 2000; Rotor, 1952 \\
\hline Miltoniopsis & $20-23$ & Long days & $150-300$ & $11-14$ & Short days & Lopez, 2003; Lopez et al., 2005; Robinson, 2002 \\
\hline Phalaenopsis & $27-30$ & No response & $240-400$ & $15-25$ & No response & $\begin{array}{l}\text { Baker and Baker, 1991; De Vries, 1950; Dole and Wilkins, 1999; } \\
\text { Griesbach, 1985; Lee and Lin, 1984, 1987; Robinson, 2002; Rotor, 1952; } \\
\text { Sakanishi et al., 1980; Wang, 1995b, 1997; Yoneda et al., 1991, } 1992\end{array}$ \\
\hline Zygopetalum & $22-26$ & Long days & $300-500$ & $11-14$ & Short days & Lopez, 2003; Lopez et al., 2003; Lopez and Runkle, 2004 \\
\hline
\end{tabular}

${ }^{\mathrm{z} C y m b i d i u m}$ is often divided into three horticultural groups based on their temperature tolerance: cool, intermediate, and warm. 


\section{9-h photoperiod}

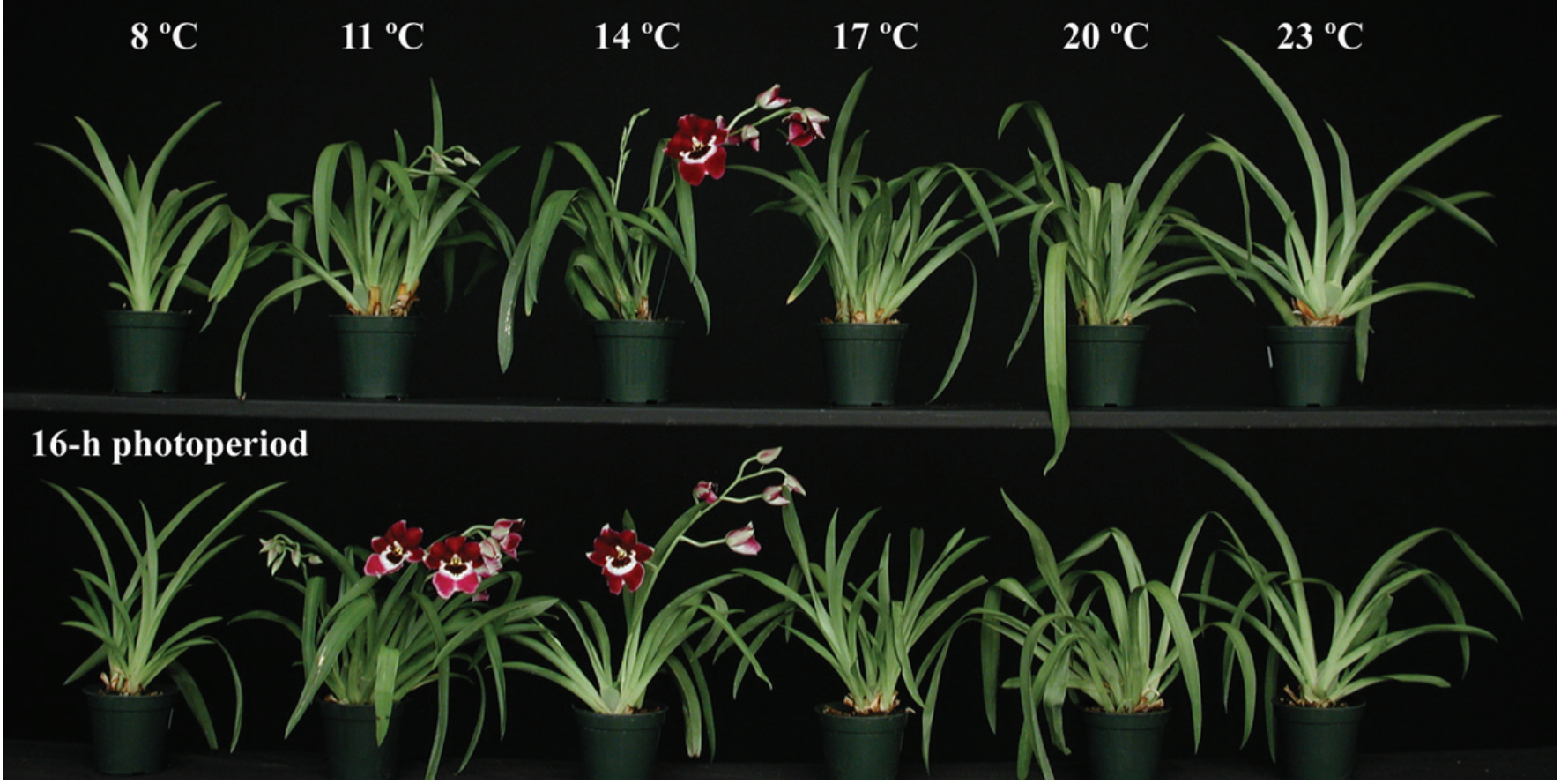

Fig. 1. Responses of Miltoniopsis Augres ‘Trinity' after a precooling photoperiod of 9-h for 8 weeks at $23{ }^{\circ} \mathrm{C}$ followed by 8 weeks at $8,11,14,17,20$, or $23{ }^{\circ} \mathrm{C}$ under a 9- or 16-h photoperiod. Plants were subsequently grown at 20 to $23{ }^{\circ} \mathrm{C}$ under a 16 -h photoperiod.

concentrations of endogenous growth regulators. Low temperature and short days could change the concentrations of endogenous growth regulators leading to induction of flowering in sympodial orchids. Sakai et al. (2000) reported that the injection of $100 \mathrm{~mm}$ 6-benzyladenine (BA) into first-year leaved stems of Dendrobium Jaquelyn Thomas 'Uniwai Princess' significantly increased the number of inflorescences (8.9) compared with untreated plants $(0.5)$. Injecting 10 or 100 mM BA into the center of the stem below the top 2 top-most vegetative buds of leafless, 2 -year-old pseudobulbs increased floral spray production (4.0 and 6.3 inflorescences, respectively) compared with that of untreated plants (0.2). However, $100 \mathrm{~mm}$ BA reduced inflorescence length and caused the development of abnormally formed flowers. The addition of $100 \mathrm{~mm}$ gibberellic acid to the BA solution increased inflorescence length and reduced the percentage of abnormally formed flowers (Sakai et al., 2000).

\section{Miltoniopsis}

Miltoniopsis is an epiphytic or lithophytic genus of six species distributed from the wet cloud forest regions (610 to $2100 \mathrm{~m}$ ) of Costa Rica to Peru (Baker and Baker, 1993; Pridgeon, 2000). Miltoniopsis performs best under relatively low light intensities of 150 to $300 \mu \mathrm{mol} \cdot \mathrm{m}^{-2} \cdot \mathrm{s}^{-1}$ (R. Lopez and E. Runkle, unpublished data).

The most complete, rapid, and uniform flowering of Miltoniopsis Augres 'Trinity' occurred when plants with half-mature pseu- dobulbs were grown under short days at $20^{\circ} \mathrm{C}$ (for 4 to 8 weeks) and then cooled at $14^{\circ} \mathrm{C}$ for 8 or more weeks (Robinson, 2002; Lopez, 2003; Lopez et al., 2005) (Table 1). Flowering percentage was reduced when short days or cooling was not provided. No more than $60 \%$ of plants initiated flowers when exposed to 16-h long days before cooling, and only $30 \%$ flowered when plants were subjected to $\geq 17$ ${ }^{\circ} \mathrm{C}$ (Lopez et al., 2005) (Fig. 1).

The effectiveness of a cooling treatment on flower initiation depends on the maturity of the pseudobulb (Lopez, 2003; Lopez et al., 2005). When an immature pseudobulb $\leq 6 \mathrm{~cm}$ in length was exposed to an inductive short day and low temperature treatment, either flowers did not initiate or time to visible inflorescence was delayed (by about 100 d). Larger, but not completely mature pseudobulbs were generally capable of initiating flowers. Therefore, Miltoniopsis has a juvenile period in which flowering does not occur until pseudobulbs have become mature to perceive inductive low temperatures. Consequently, growers need to coordinate the cooling period with pseudobulb maturity to achieve the most rapid and uniform flowering of Miltoniopsis.

Once Miltoniopsis has initiated flowers, flower development time is a function of temperature. Time from visible inflorescence to first open flower at $14,17,20$ or $23^{\circ} \mathrm{C}$ was 127 , 99, 78 and $62 \mathrm{~d}$, respectively, for Miltoniopsis Augres 'Trinity' (R. Lopez, unpublished data). After flower initiation, flower size and quality were adversely affected when light intensity was $\geq 400 \mu \mathrm{mol} \cdot \mathrm{m}^{-2} \cdot \mathrm{s}^{-1}$ or temperature was $>20$ ${ }^{\circ} \mathrm{C}$ (Robinson, 2002).

\section{Phalaenopsis}

Phalaenopsis contains $>50$ species originating from tropical and subtropical areas of the South Pacific Islands and Asia (Pridgeon, 2000). Their distribution extends from southern India to Australia, including China, Taiwan, and the Philippines.

Phalaenopsis orchids remain vegetative above 27 to $29^{\circ} \mathrm{C}$ (Sakanishi et al., 1980) and can tolerate temperatures as high as 32 to 35 ${ }^{\circ} \mathrm{C}$ for short periods before exhibiting signs of heat stress (Baker and Baker, 1991). The calculated base temperature for Phalaenopsis is 10.8 to $11.2^{\circ} \mathrm{C}$ for all developmental stages (Robinson, 2002). Phalaenopsis exposed to temperatures of 2,4 , or $7{ }^{\circ} \mathrm{C}$ for $1,2,4$ and 8 hours developed chilling injury symptoms, including sunken, yellow, water-soaked spots on upper leaf surfaces (McConnell and Sheehan, 1978).

Phalaenopsis requires a period of exposure to relatively moderate temperature $\left(<26{ }^{\circ} \mathrm{C}\right)$ to trigger the initiation of the inflorescence, or spiking (Lee and Lin, 1984, 1987; Sakanishi et al., 1980; Wang, 1995b; Yoneda et al., 1992). The inflorescence usually emerges from the third and often the forth node below the apical leaf(Sakanishi et al., 1980). Flower bud initiation occurs after the spike has reached about 5 $\mathrm{cm}$ in length if environmental conditions are favorable. Lee and Lin (1984) showed that uniform spiking can be achieved when plants are grown at day/night temperatures of $25 / 20^{\circ} \mathrm{C}$ or $20 / 15^{\circ} \mathrm{C}$ for 4 to 5 weeks. Recent research indicates that constant temperatures of 20,23, or $25{ }^{\circ} \mathrm{C}$ can initiate flowering in a variety of 
Phalaenopsis (Blanchard and Runkle, 2004; Y.-T. Wang, unpublished data).

Once the flowering spike has initiated, time to the first open flower is a function of the average daily temperature. However, if a plant with an inflorescence $<10 \mathrm{~cm}$ is subsequently grown at $28^{\circ} \mathrm{C}$ or higher for extended periods, a spike can form a vegetative air plantlet referred to as a "keiki" instead of flower buds, buds may abort, or the stem may elongate indefinitely without open flowers (Sakanishi et al., 1980; Wang, 1995b). Temperature has little or no effect on spike height or flower size (Robinson, 2002; Sakanishi et al., 1980).

In 2002, Robinson conducted experiments to quantify the effects of temperature (from 14 to $29{ }^{\circ} \mathrm{C}$ ) on time from spike emergence to flowering and on plant quality. The rate of flower development for all three hybrids of Phalaenopsis studied increased linearly as temperature increased from 14 to $26^{\circ} \mathrm{C}$. For example, as temperature increased from 20 to $23{ }^{\circ} \mathrm{C}$, days from visible flower bud to first flower opening decreased from 50 to $35 \mathrm{~d}$.

A few studies reported that short days enhance spiking and spike length, and long days promote vegetative growth and the development of aerial plantlets (De Vries, 1953; Griesbach, 1985; Rotor, 1952; Yoneda et al, 1991). For example, Yoneda et al. (1991) found that flowering percentages were $50 \%$ and $79 \%$ when 6 year-old seedlings were grown under natural days and $8-\mathrm{h} \mathrm{SD}$, respectively, at 22 or $23{ }^{\circ} \mathrm{C}$. However, time to spike emergence was not significantly different. The short-day promotion of flowering could be a result of the extension of cool night temperatures and not daylength itself (Sakanishi et al., 1980). Therefore, it is unclear if photoperiod has a weakly quantitative effect on flowering of $P h a$ laenopsis (Baker and Baker, 1991; Sakanishi et al., 1980). Application of gibberellic acid $\left(\mathrm{GA}_{4+7}\right)$ as a foliar spray or to one leaf axil per plant did not promote spiking or keiki formation in Phalaenopsis (Wang, 1995a).

The recommended light intensity for growth and development of Phalaenopsis is between 200 and $400 \mu \mathrm{mol} \cdot \mathrm{m}^{-2} \cdot \mathrm{s}^{-1}$ (Dole and Wilkins, 1999; Wang, 1997). Konow and Wang (2001) demonstrated that there is a minimum lightintensity required for in vitro growth and greenhouse flowering. In their study, $2 \%, 77 \%$, and $98 \%$ of Phalaenopsis Atien Kaala seedlings flowered when grown under a maximum instantaneous irradiance of 52,108 , or $240 \mu \mathrm{mol} \cdot \mathrm{m}^{-2} \cdot \mathrm{s}^{-1}$. Plants also had longer, wider, thicker, and more leaves when provided with higher irradiances. Research by Wang (1995) revealed that a moderate light intensity was required during cooling to induce flowering; plants grown at $20 / 15^{\circ} \mathrm{C}$ under 60 or $160 \mu \mathrm{mol} \cdot \mathrm{m}^{-2} \cdot \mathrm{s}^{-1}$ spiked in 34 or $28 \mathrm{~d}$, respectively, and those provided with either 0 or $8 \mu \mathrm{mol} \cdot \mathrm{m}^{-2} \cdot \mathrm{s}^{-1}$ did not spike within 6 weeks. The negation of spiking in darkness despite inductive temperature could be used by growers to delay flowering when temperature is sufficiently low to induce flowering. For example, alternating days in darkness with days in light (e.g., 4 to $5 \mathrm{~d}$ of darkness each week) inhibits spiking of Phalaenopsis (Wang, 1997, 1998).

\section{Zygopetalum}

Zygopetalum, or the ladybird orchid, is a sympodial, terrestrial, and epiphytic South American genus composed of about 20 species. They are native to neotropic midelevation mountains (1300 to $1700 \mathrm{~m}$ ) of Brazil, Guiana, Venezuela, and Peru (Rose, 1993). Vegetative growth is most rapid at $26^{\circ} \mathrm{C}$, but a temperature of $23{ }^{\circ} \mathrm{C}$ is suggested to balance growth rate with desirable growth characteristics (e.g., long leaves) (Lopez, 2003) (Table 1). Black necrotic lesions can form when light intensity exceeds about $500 \mu \mathrm{mol} \cdot \mathrm{m}^{-2} \cdot \mathrm{s}^{-1}(\mathrm{R}$. Lopez and E. Runkle, unpublished data).

The most rapid, complete, and uniform flowering of Zygopetalum Redvale 'Fire Kiss' occurred when plants were grown under short days and then cooled at 11 to $14{ }^{\circ} \mathrm{C}$ for about 8 weeks (Lopez et al., 2003). A population of Zygopetalum plants exposed to long days before cooling had a lower flowering percentage ( $\leq 60 \%$ ), compared to $80 \%$ for plants exposed to short days. When plants were cooled at 17 or 20 ${ }^{\circ} \mathrm{C}$, the flowering percentage was also reduced $(\leq 50 \%)$. Therefore, a short photoperiod followed by cool temperature $\left(11\right.$ to $\left.14{ }^{\circ} \mathrm{C}\right)$ stimulates the flowering process. After the cooling period, time to visible inflorescence was relatively rapid at $23{ }^{\circ} \mathrm{C}$ (about 3 weeks). Average time from visible inflorescence to flower at 14, 17, 20,23, and $26^{\circ} \mathrm{C}$ was $64,49,40,34,30 \mathrm{~d}$, respectively (Lopez and Runkle, 2004).

The inflorescence of Zygopetalum generally arises out of very young, developing pseudobulbs. In our research, we have observed that for a cooling period to induce flowering, it must be delivered when new pseudobulbs are immature ( $<8 \mathrm{~cm}$ in length) at the onset of the cooling period. If shoots are more mature (e.g., $12 \mathrm{~cm}$ or longer) at the beginning of cooling, then flower initiation does not usually occur. Thus, Zygopetalum initiates flowers on emerging pseudobulbs, whereas Miltoniopsis initiates flowers on relatively mature pseudobulbs.

\section{Summary}

Flowering of many of the most commonly grown orchid genera is influenced by temperature and light. In particular, a relatively low temperature induces flowering, while a high temperature inhibits it. For many of these genera, an inductive temperature is about $12{ }^{\circ} \mathrm{C}$, but it is much higher $\left(\leq 25^{\circ} \mathrm{C}\right)$ for Phalaenopsis (Table 1). For some species and hybrids of Cattleya, Dendrobium, Miltoniopsis, and Zygopetalum, the combination of short photoperiod and low temperature induces flowering in the most complete, rapid, and uniform manner. With this information, it may be possible for greenhouse growers to induce a variety of orchid genera into flowering using a common cool environment (about $12{ }^{\circ} \mathrm{C}$ ). However, for many orchids, the delivery of a cool temperature treatment must coincide with a developmental stage in which plants are sensitive to an inductive low temperature treatment. Once flower buds have initiated, flower development time is dependant upon genotype and temperature.
Potted flowering orchids is a promising crop category that offers greenhouse growers a profitable alternative to other floriculture crops currently grown in the United States. With the increasing popularity and production of orchids throughout the world, further research is needed to determine the cultural and flower inductive requirements of other orchid hybrids. In addition, more information is needed on orchid genera currently grown because the specific inductive requirements can vary from one hybrid to another. This information will enable growers to produce more diverse flowering orchid plants for specific market dates and give consumers alternatives to traditional crops such as poinsettias for Christmas or Easter lilies for Easter.

\section{Literature Cited}

American Orchid Society. 2002. Dendrobium: The American Orchid Society culture sheets. 17 Aug. 2005. http://www.aos.org/aos/uploadedfiles/docs/culturedendrobe.pdf

Baker, M.L. and C.O. Baker. 1991. Orchid species culture. Timber Press, Portland, Ore.

Baker, M.L. and C.O. Baker. 1993. Miltoniopsis. Amer. Orchid Soc. Bul. 62:794-799.

Baker, M.L. and C.O. Baker. 1996. Orchid species culture: Dendrobium. Timber Press, Portland, Ore.

Barendse, M. 2002. De sierteelt-toppers van 2001. Vakblad voor de Bloemisterij 2:24-27.

Blanchard, M.G. and E. Runkle. 2004. Temperature effects on flower induction of two Phalaenopsis orchid hybrids. HortScience 39:882.

De Vries, J.T. 1953. On the flowering of Phalaenopsis schilleriana RCHB. f. Annu. Bogorienses 1:61-76.

Dole, J. and H. Wilkins. 1999. Floriculture principles and species. Prentice-Hall, Upper Saddle River, N.J.

Eigeldinger, O. and L.S. Murphy. 1972. Orchids: a complete guide to cultivation. Drake Publ., New York.

Goh, C.J. and J. Arditti. 1985. Orchidaceae, p. 309-336. In: A.H. Halevy (ed.). Handbook of flowering. vol. I. CRC Press, Boca Raton, Fla.

Goh, C.J., M.S. Strauss, and J. Arditti. 1982. Flower induction and physiology in orchids, p. 213-241. In: J. Arditti (ed.). Orchid biology: Reviews and perspectives. vol. 2. Cornell Univ. Press, New York.

Griesbach, R.J. 1985. An orchid in every pot. Florists' Rev. 176:26-30.

Griesbach, R.J. 2000. Potted Phalaenopsis orchid production: history, present status, and challenges for the future. HortTechnology 10:429.

Griesbach, R.J. 2002. Development of Phalaenopsis orchids for the mass-market, p. 458-465. In: J. Janick and A. Whipkey (eds.). Trends in new crops and new uses. ASHS Press, Alexandria, Va.

Hew, C.S. and J.W.H. Yong. 1997. The physiology of tropical orchids in relation to the industry. World Scientific, Singapore.

Ichihashi, S. 1997. Orchid production and research in Japan, p. 171-212. In: J. Arditti and A.M. Pridgeon (eds.). Orchid biology: Reviews and perspectives. vol. 7. Kluwer Academic Publ., Dordrecht, The Netherlands.

Konow, E.A. and Y.-T. Wang. 2001. Irradiance levels affect in vitro and greenhouse growth, flowering, and photosynthetic behavior of a hybrid Phalaenopsis orchid. J. Amer. Soc. Hort. Sci. 126:531-536.

Kostenyuk, I., B.J. Oh, and I.S. So. 1999. Induction of 
early flowering of Cymbidium niveo-marginatum Mak in vitro. Plant Cell Rpt. 19:1-5.

Krizek, D.T. and R.H. Lawson. 1974. Accelerated growth of Cattleya and Phalaenopsis under controlled-environment conditions. Amer. Orchid Soc. Bul. 43:503-510.

Laws, N. 2004. The world's fascination with potted orchids. Floracult. Intl. 14(12):26-27.

Lee, N. and C.Z. Lee. 1993. Growth and flowering of Cymbidium ensifolium var. misericors as influenced by temperature. Acta Hort 337:123-130.

Lee, N. and G.M. Lin. 1984. Effect of temperature on growth and flowering of Phalaenopsis white hybrid. J. Chinese Soc. Hort. Sci. 30:223-231.

Lee, N. and G.M. Lin. 1987. Controlling the flowering of Phalaenopsis, p. 27-44. In: L.R. Chang. (ed.) Proc. Symp. Forcing Hort. Crops. Special Publ. 10. Taichung District Agr. Improvement Sta., Changhua, Taiwan, Republic of China.

Leonhardt, K.W. 2000. Potted, blooming Dendrobium orchids. HortTechnology 10:431.

Lopez, R.G. 2003. Effects of photoperiod and temperature on growth and flowering of six orchid hybrids. MS thesis. Mich. State Univ., East Lansing.

Lopez, R.G. and E.S. Runkle. 2004. The effect of temperature on leaf and flower development and flower longevity of Zygopetalum Redvale 'Fire Kiss' orchid. HortScience 39:1630-1634.

Lopez, R.G., E.S. Runkle, and R.D. Heins. 2005. Flowering of the orchid Miltoniopsis Augres 'Trinity' is influenced by photoperiod and temperature. Acta Hort. 683:175-179.

Lopez, R.G., E.S. Runkle, R.D. Heins, and C.M. Whitman. 2003. Temperature and photoperiodic effects on growth and flowering of Zygopetalum Redvale 'Fire Kiss' orchids. Acta Hort. 24:155-162.

McConnell, D.B. and T.J. Sheehan. 1978.Anatomical aspects of chilling injury to leaves of Phalaenopsis B1. Hort Sci. 13:705-706.

Nash, N. 2003. Phalaenopsis primer: A beginner's guide to growing moth orchids. Amer. Orchid Soc. Bul. 72:908-912.

Ohno, H. 1991. Microsporogenesis and flower bud blasting as affected by high temperature and gibberelic acid in Cymbidium (Orchidaceae). J. Jpn. Soc. Hort. Sci. 60:149-257.

Powell, C.L., K.I. Caldwell, R.A. Littler, and I. Warrington.1988. Effect of temperature regime and nitrogen fertilizer level on vegetative and reproductive bud development in Cymbidium orchids. J. Amer. Soc. Hort. Sci. 113:552-556.

Pridgeon, A. 2000. The illustrated encyclopedia of orchids. Timber Press, Portland, Ore.

Robinson, K.A. 2002. Effects of temperature on the flower development rate and morphology of Phalaenopsis orchid. MS thesis. Mich. State Univ., East Lansing.

Rose, J. 1993. Zygopetalum. Amer. Orchid Soc. Bull. 62:733-734

Rotor, G.B. 1952. Daylength and temperature in relation to growth and flowering of orchids. Cornell Univ. Agr. Expt. Sta. Bul. 885:3-47.

Rotor, G.B. 1959. The photoperiodic and temperature responses of orchids, p. 397-416. In: C.L. Withner (ed.). The orchids. Ronald Press, New York.

Sakai, W.S., C. Adams, and G. Braun. 2000. Pseudobulb injected growth regulators as aid for year around production of Hawaiian Dendrobium orchid cutflowers. Acta Hort. 541:215-220.
Sakanishi, Y., H. Imanishi, and G. Ishida. 1980. Effect of temperature on growth and flowering of Phalaenopsis amabilis. Bul. Univ. Osaka, Series B.Agr. Biol.-Osaka (Prefecture) Daigaku 32:1-9.

U.S. Department of Agriculture. 1998. Floriculture crops 1997 summary. Agr. Stat. Board, Wash., D.C.

U.S. Department of Agriculture. 2005. Floriculture crops 2004 summary. Agr. Stat. Board, Wash., D.C.

Wang, Y.-T. 1995a. Gibberellic acid on Phalaenopsis. Amer. Orchid Soc. Bul. 64:744.

Wang, Y.-T. 1995b. Phalaenopsis orchid light requirement during the induction of spiking. HortScience 30:59-61.

Wang, Y.-T. 1997. Phalaenopsis light requirements and scheduling of flowering. Orchids 66:934-939.

Wang, Y.-T. 1998. Deferring flowering of greenhouse-grown Phalaenopsis orchids by alternating dark and light. J. Amer. Soc. Hort. Sci. 123:56-60.

Wang, Y.-T. 2004. Flourishing market for potted orchids. FlowerTech 7:14-17.

Went, F.W. 1957. The experimental control of plant growth. Chron. Bot. 17:148-152.

Yoneda, K., H. Momose, and S. Kubota. 1991. Effects of daylength and temperature on flowering in juvenile and adult Phalaenopsis plants. J. Jpn. Soc. Hort. Sci. 60:651-657.

Yoneda, K., H. Momose, and S. Kubota. 1992. Comparison of flowering behavior between mature and premature plants of Phalaenopsis under different temperature conditions. Trop. Agr. 36:207-210. 